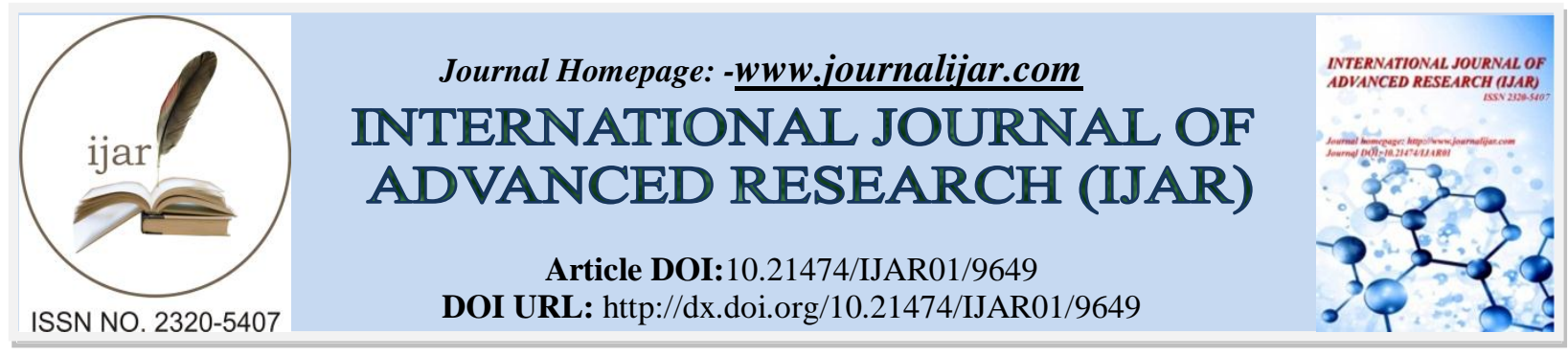

RESEARCH ARTICLE

\title{
PRIMING IMPROVES GERMINATION AND SEEDLING GROWTH PERFORMANCE OF ACCELERATED AGED SEEDS OF TOMATO.
}

\author{
Chinka Batra ${ }^{1}$, Namarta Gupta ${ }^{2}$ and Prinka Goyal ${ }^{3}$. \\ 1. Research Fellow, Dept. of Soil Science, Punjab Agricultural University, Ludhiana. \\ 2. Associate Professor, Dept. of Botany, Punjab Agricultural University, Ludhiana. \\ 3. Assistant Professor, Dept. of Botany, Punjab Agricultural University, Ludhiana.
}

\section{Manuscript Info}

Manuscript History

Received: 04 July 2019

Final Accepted: 06 August 2019

Published: September 2019

\begin{abstract}
Seed priming is a cost effective technique which not only improves seed germination but also reduces time of seedling emergence and improves stand establishment. The present study was conducted to study the effect of various seed priming treatments (Hydration, $\mathrm{KNO}_{3}$ and $\mathrm{GA}_{3}$ ) on percent germination and growth indices of two tomato cultivars Varkha Bahar-1 and Varkha Bahar-2. Seed priming improved all morphological parameters such as percentage germination, seedling length, seedling fresh and dry weight and vigour index as compared to control. Seed priming with $\mathrm{GA}_{3}$ showed more promotry effect followed by $\mathrm{KNO}_{3}$ and hydration at higher concentration. Similarly seed treatment for 48 hrs showed more promotory effect as compared to 24 hrs treatment in both the cultivars at both concentrations although the effect was more pronounced in Varkha Bahar-1 as compared to Varkha Bahar-2.
\end{abstract}

Copy Right, IJAR, 2019,. All rights reserved.

\section{Introduction:-}

Tomato is one of the most important vegetable crops which is grown throughout the world (Choudhury et al 2013). China, the largest producer, accounted for about one quarter of the global output, followed by United States of America, India and Turkey (Patel and Rai 2018). In India, it is an important cash crop for small-holders and medium-scale commercial farmers. Seed, being a basic and crucial input, plays an important role in crop production. Hence, use of quality seeds is an effective means of improving the crop yield. Recently, many strategies have been applied to improve seed quality based on genetic and physiological approaches. Among the various strategies, priming is one of the most important physiological methods which improves the seed performance and provides faster and synchronized germination (Ashraf and Foolad 2005, Paparella et al 2015). Various seed priming techniques, have been developed in crop plants, which include hydro priming (soaking in water), halo-priming (soaking in inorganic salt solutions $\mathrm{NaCl}, \mathrm{KNO}_{3}, \mathrm{CaCl}_{2}$ etc.), osmo priming (soaking in organic osmoticum like sugar, PEG etc.) and hormonal priming (soaking in different hormones like GA, kinetin etc.) (Paparella et al 2015, Hussain et al 2016). Ahmadvand (2012 a, b) observed rapid seed germination and uniform emergence by seed priming technology along with improved seedling establishment under stress conditions. Priming with potassium nitrate (KNO3), PEG and $\mathrm{NaCl}$ have been shown to improve the seed germination, seedling emergence and the initial growth of various plant species (Zhang et al 2012). The present research was planned to investigate the effect

Corresponding Author:-ChinkaBatra.

Address:-Research fellow in dept. of soil science, Punjab Agricultural University, Ludhiana. 
of hydro and hormonal priming and duration of priming on seedling growth performance of accelerated aged seeds of tomato.

\section{Materials And Methods:-}

The present study was conducted in Plant Physiology laboratory, Seed Technology Centre of Punjab Agricultural University, Ludhiana. It is situated at $30^{\circ}-54^{\circ} \mathrm{N}$ latitude, $75^{\circ}-45^{\circ} \mathrm{E}$ longitude and at a mean height of 247 meters above sea level. It is placed in south-Central plain region of Punjab having subtropical and semi-arid climate.

The seeds of two cultivars of tomato Punjab Varkha Bahar-1 and Punjab Varkha Bahar-2 were procured from the Director Seeds, PAU Ludhiana and used for studies pertaining to seed germination, early seedling growth and vigour index after artificially accelerated aging. For accelerated aging, the seeds were kept in dessicator at $40^{\circ} \mathrm{C}$ and $100 \% \mathrm{RH}$ for 72 hours. The treatments were allotted in completely randomized design (CRD) in three replications. The following treatments were included:

T0- Control -No treatment

T1- Hydration - for 24 and 48 hours at $25^{\circ} \mathrm{C}$

T2- $\mathrm{KNO}_{3}-50 \mathrm{mM}$ for 24 and 48 hours at $25^{\circ} \mathrm{C}$

T3- $\mathrm{KNO}_{3}-150 \mathrm{mM}$ for 24 and 48 hours at $25^{\circ} \mathrm{C}$

T4- $\mathrm{GA}_{3}-10 \mathrm{ppm}$ for 24 and 48 hours at $25^{\circ} \mathrm{C}$

T5- $\mathrm{GA}_{3}-20 \mathrm{ppm}$ for 24 and 48 hours at $25^{\circ} \mathrm{C}$

The accelerated aged seeds of both tomato cutivars were sterilized by dipping in sodium hypochlorite solution (5\%) for five minutes followed by drying on filter paper. Fifty seeds of each variety were subjected to hydro-priming (water), hormonal priming $\left(\mathrm{GA}_{3}\right)$ and chemical priming $\left(\mathrm{KNO}_{3}\right)$ for 24 and $48 \mathrm{hrs}$. After seed treatments, seedlings were raised between the two layers of germination paper kept in growth chamber with temperature of $25 \pm 2^{\circ} \mathrm{C}$. Effect of seed treatments was assesed in terms of percent seed germination, seedling length $(\mathrm{cm})$, seedling fresh and dry weight $(\mathrm{mg})$ and vigour index at 14 DAS. The germination percentage was expressed as per ISTA rules (ISTA 2008).

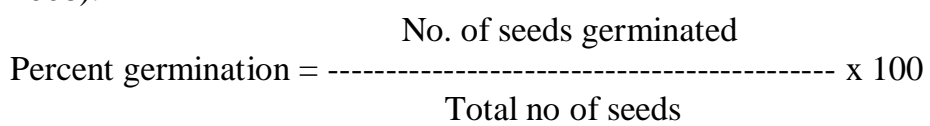

To determine seedling length, ten normal seedlings from each replication were taken. The root (from the collar region to the tip of root) and shoot length (from the collar region to the point of attachment of cotyledons) were measured using centimetre scale. Average root and shoot length of ten seedlings was expressed in centimeters. The fresh and dry weight of ten healthy seedlings was recorded in milligrams with the help of weighing balance. Vigour index of seeds were calculated as suggested by Abdul Baki's Anderson (1973). The data on seedling growth parameters were evaluated and analysis of variance (ANOVA) was done statistically using CPCS1 software. The effect of seed treatments, duration of seed treatment and cultivars were evaluated by the least significant difference (LSD) test at $\mathrm{P}<0.05$.

\section{Results And Discussion:-}

According to the results, all seedling characters viz. germination percent, root length $(\mathrm{cm})$, shoot length $(\mathrm{cm})$, seedling fresh weight and dry weight (gms) and seedling vigour index were affected by the priming treatments in both cultivars and there was completely significant difference between control (unprimed seeds) and primed seeds.

\section{Percent germination}

Seed germination and seedling growth, are two critical stages for plant establishment and the most sensitive to abiotic stress (Patade et al 2011). The data regarding percent germination of unprimed (UP) and chemical, water and hormonal primed seeds of tomato is represented in Table 1. All priming treatments were effective in ameliorating the detrimental effects of seed aging. Seeds primed for $48 \mathrm{hrs}$ with $\mathrm{GA}_{3} @ 20 \mathrm{ppm}$ showed maximum percent germination i.e. 86.4 in Varkha Bahar-1 and 83.8 in Varkha Bahar-2. Seed treatment with GA $@ 20$ ppm for 24 hrs also showed more percent germination but percent germination was recorded low as compared to $48 \mathrm{hrs}$ treatment in both the cultivars. Similarly, seed priming with $\mathrm{KNO}_{3} @ 150 \mathrm{mM}$ for $48 \mathrm{hrs}$ resulted in higher percent germination as compared to $\mathrm{KNO}_{3}$ at $50 \mathrm{mM}$ in both cultivars but Varkha Bahar-1 showed more percent germination than Varkha Bahar-2. This finding is in conformity with reports of other researchers such as Harris (2002) in wheat, Ghassimi et al (2008) on lentil and Bradfor et al (1990) on pepper. Seed priming stimulates many of the metabolic processes involved with the early phases of germination. Priming with potassium nitrate (KNO3), PEG or $\mathrm{NaCl}$ 
have been shown to improve the germination, seedling emergence and the initial growth of various plant species (Govinden and Levantard 2008, Zhang et al 2012).

\section{Fresh and dry weight}

The results showed that the effect of priming was significant on fresh weight of seedlings (Table 2). Maximum seedling fresh weight (492 mgs) was reported with GA3 @ 20ppm primed seeds followed by GA 3 @ 10ppm (474 mgs) primed seeds for 48 hrs. Same trend was observed when seeds were primed with GA 3 for 24 hrs at both concentrations. Lowest value of seedling fresh weight found in unprimed seeds i.e. control (395 mgs). Seed priming with $\mathrm{KNO}_{3}$ for $48 \mathrm{hrs}$ with both the concentrations $50 \mathrm{mM}$ and $150 \mathrm{mM}$ showed an increase in fresh weight as compared to $24 \mathrm{hrs}$ seed treatment, but more increase was observed in Varkha Bahar-1 than Varkha Bahar-2. The hydration treatment of seeds showed an increase in seedling fresh weight of seedlings of both the varieties Varkha Bahar-1 and Varkha Bahar-2 as compared to control, but more increase was observed in Varkha Bahar-1 when the seeds were hydrated for $48 \mathrm{hrs}$ on comparison with $24 \mathrm{hrs}$.

The dry weight of seedlings differed significantly among the treatments and cultivars at both durations (Table 3). The hydration treatment increased the dry weight of seedling over control (9.5 in Varkha Bahar-1 and 9.0 in Varkha Bahar-2). The dry weight of seed increased with increase in duration of hydro-priming (48 hrs) (12.0 in Varkha Bahar-1 and 10.9 in Varkha Bahar-2) as compared to 24 hrs (11.4 in Varkha Bahar-1 and 10.3 in Varkha Bahar-2). Varkha Bahar-1 showed more increase in dry weight as compared to Varkha Bahar-2 with all the treatments. Among the $\mathrm{KNO}_{3}$ treated seeds, the seeds soaked for $24 \mathrm{hrs}$ in $50 \mathrm{mM} \mathrm{KNO}$ recorded the less dry weight of seedlings as compared to the seeds treated with $150 \mathrm{mM}$ for $24 \mathrm{hrs}$. Priming with $\mathrm{GA}_{3}$ at both the concentrations $(10 \mathrm{ppm}$ and 20 ppm) for $48 \mathrm{hrs}$ showed the maximum dry weight of seedlings. $\mathrm{GA}_{3}$ seed treatment with 20 ppm showed more dry weight as compared to $\mathrm{GA}_{3}$ with $10 \mathrm{ppm}$ concentration. Similar effect was notified in the seed treatment for $48 \mathrm{hrs}$ which showed more dry weight content on comparison with $24 \mathrm{hrs}$ in both the varieties. But, Varkha Bahar-1 showed more dry weight as compared to Varkha Bahar-2.

\section{Shoot length and root length}

The data revealed that shoot length was affected by different priming treatments, and length was significantly different across varieties (Table 4). Trends of changes in shoot length with seed priming were similar in root length. Priming with solutions of KNO3, GA3 and water exhibited the improved shoot length, while least shoot length was recorded in control. Faster seed-germination can cause greater shoot and root length in treated seeds. Nascimento (2003) has reported that the pre-treatment of melon seeds with different solutions increased plumule length resulted from the longer period of time for seedling growth as a result of a faster germination.

Significant differences were found to exist between the varieties and among the priming treatments on root length (Table 5). The hydro-primed seeds for $48 \mathrm{hrs}$ showed more increase in the root length than 24 hrs in both tomato varieties Varkha Bahar-1 and Varkha Bahar-2. Varkha Bahar-2 showed less shoot length than Varkha Bahar-1. $\mathrm{KNO}_{3} @ 150 \mathrm{mM}$ also increased root length on seed treatment for 48 hrs as compared to 24 hrs. Similar trend was observed in seed treatment of accelerated aged seeds with $50 \mathrm{mM} \mathrm{KNO}_{3}$ but increase was observed when the seeds were treated for $48 \mathrm{hrs}$ duration as compared to $24 \mathrm{~h}$. The hydration treatments for $48 \mathrm{~h}$ showed an increase as compared to $24 \mathrm{~h}$ seed treatment along with control in Varkha Bahar-1. Similar effect was observed in the hydrated accelerated aged seeds of Varkha Bahar-2. While the effect was more pronounced in Varkha Bahar-1 than Varkha Bahar-2._Demir and Oztokat (2003) also found that root and shoot length increased in seeds due to hormonal priming as compared to non-primed seeds. Similar finding were also reported by Farooq (2007).

\section{Vigour Index}

All seed priming treatment showed positive effect on the seedling vigour index (Table 6). Maximum seedling vigour index (1283.52) was recorded when seeds were primed with GA3 @ 20ppm followed by GA3 @ 10 ppm (1117.20) for 48 hrs (Table 6). Seed priming with $\mathrm{GA}_{3}$ at both concentrations for $24 \mathrm{hrs}$ showed same trend but it was recorded lower as compared to treatment for $48 \mathrm{hrs}$. Similarly, seed treatment with $\mathrm{KNO}_{3}$ at both the concentrations $(50 \mathrm{mM}$ and $150 \mathrm{mM}$ ) showed higher vigour index as compared to control although more increase was observed with $\mathrm{KNO}_{3}$ @ 150 mM. Minimum seedling vigour index (479.75) was recorded in unprimed seeds (control). Kathiresan et al (1984) reported the increase in seedling vigour which may be due to enhanced oxygen uptake and the efficiency of mobilizing nutrients from the cotyledons to the embryonic axis. Bakht 2011 and Ruan et al 2002 reported similar findings. 
Table 1:-Effect of seed priming for 24 and $48 \mathrm{hrs}$ on percent seed germination of two tomato (Lycopersicon esculentum L.) cultivars Varkha Bahar-1 and Varkha Bahar-2.

\begin{tabular}{|c|c|c|c|c|}
\hline \multirow[t]{2}{*}{ TREATMENTS } & \multicolumn{2}{|c|}{ VARKHA BAHAR-1 } & \multicolumn{2}{|c|}{ VARKHA BAHAR-2 } \\
\hline & $24 \mathrm{~h}$ & $48 h$ & $24 \mathrm{~h}$ & $48 h$ \\
\hline CONTROL & 60.5 & 60.5 & 58.5 & 58.5 \\
\hline HYDRATION & 60.2 & 69.1 & 62.4 & 65.6 \\
\hline $\mathrm{KNO}_{3}(50 \mathrm{mM})$ & 70.6 & 75.6 & 67.6 & 70.5 \\
\hline $\mathrm{KNO}_{3}(150 \mathrm{mM})$ & 73.7 & 79.2 & 71.8 & 75.4 \\
\hline $\mathrm{GA}_{3}(10 \mathrm{ppm})$ & 78.8 & 83.5 & 76.1 & 80.1 \\
\hline $\mathrm{GA}_{3}(20 \mathrm{ppm})$ & 82.6 & 86.4 & 80.3 & 83.8 \\
\hline CD at $5 \%$ & \multicolumn{4}{|c|}{$\mathrm{A}=0.8203, \mathrm{~B}=0.4736, \mathrm{C}=0.4736, \mathrm{ABC}=1.6407$} \\
\hline
\end{tabular}

Table 2:- Effect of seed priming for $24 \mathrm{hrs}$ and $48 \mathrm{hrs}$ on fresh weight (mgs) of seedlings of two tomato (Lycopersicon esculentum L.) cultivars Varkha Bahar-1 and Varkha Bahar-2.

\begin{tabular}{|l|c|c|c|c|}
\hline \multirow{2}{*}{ TREATMENTS } & \multicolumn{2}{|c|}{ VARKHA BAHAR-1 } & \multicolumn{2}{c|}{ VARKHA BAHAR-2 } \\
\cline { 2 - 5 } & $\mathbf{2 4} \mathbf{~ h}$ & $\mathbf{4 8} \mathbf{~}$ & $\mathbf{2 4} \mathbf{~ h}$ & $\mathbf{4 8} \mathbf{~ h}$ \\
\hline CONTROL & 395 & 395 & 378 & 378 \\
\hline HYDRATION & 417 & 429 & 396 & 411 \\
\hline KNO $_{\mathbf{3}}(\mathbf{5 0 m M})$ & 439 & 450 & 420 & 431 \\
\hline KNO $_{\mathbf{3}}(\mathbf{1 5 0 m M})$ & 455 & 461 & 432 & 446 \\
\hline GA $_{\mathbf{3}}(\mathbf{1 0 p p m )}$ & 468 & 474 & 445 & 459 \\
\hline GA $_{\mathbf{3}}(\mathbf{2 0 p p m )}$ & 481 & 492 & 466 & 473 \\
\hline CD at 5\% & \multicolumn{2}{|c|}{$\mathrm{A}=0.8836, \mathrm{~B}=0.5101, \mathrm{C}=0.5101, \mathrm{ABC}=1.7673$} \\
\hline
\end{tabular}

Table 3:- Effect of seed priming for $24 \mathrm{hrs}$ and $48 \mathrm{hrs}$ on percentage germination dry weight (mgs) of seedlings in two tomato (Lycopersicon esculentum L.) cultivars Varkha Bahar-1 and Varkha Bahar-2.

\begin{tabular}{|l|c|c|c|c|}
\hline \multirow{2}{*}{ TREATMENTS } & \multicolumn{2}{|c|}{ VARKHA BAHAR-1 } & \multicolumn{2}{c|}{ VARKHA BAHAR-2 } \\
\cline { 2 - 5 } & $\mathbf{2 4} \mathbf{~ h}$ & $\mathbf{4 8} \mathbf{~ h}$ & $\mathbf{2 4} \mathbf{~ h}$ & $\mathbf{4 8 ~} \mathbf{~}$ \\
\hline CONTROL & 9.5 & 9.5 & 9.0 & 9.0 \\
\hline HYDRATION & 11.4 & 12.0 & 10.3 & 10.9 \\
\hline KNO $_{\mathbf{3}}(\mathbf{5 0 m M})$ & 12.6 & 13.3 & 11.7 & 12.4 \\
\hline KNO $_{\mathbf{3}}(\mathbf{1 5 0 m M})$ & 13.5 & 14.1 & 12.6 & 13.3 \\
\hline GA $_{\mathbf{3}}(\mathbf{1 0 p p m})$ & 14.3 & 15.2 & 13.2 & 14.4 \\
\hline GA $_{\mathbf{3}}(\mathbf{2 0} \mathbf{p p m})$ & 14.9 & 16.8 & 14.3 & 15.5 \\
\hline CD at 5\% & \multicolumn{4}{|c|}{$\mathrm{A}=0.8205, \mathrm{~B}=0.4737, \mathrm{C}=0.4737, \mathrm{ABC}=\mathrm{NS}$} \\
\hline
\end{tabular}

Table 4:- Effect of seed priming for 24 and 48 hrs on shoot length (cms) of seedlings of two tomato (Lycopersicon esculentum L.) cultivars Varkha Bahar-1 and Varkha Bahar-2.

\begin{tabular}{|l|c|c|c|c|}
\hline \multirow{2}{*}{ TREATMENTS } & \multicolumn{2}{|c|}{ VARKHA BAHAR-1 } & \multicolumn{2}{c|}{ VARKHA BAHAR-2 } \\
\cline { 2 - 5 } & $\mathbf{2 4} \mathbf{~ h}$ & $\mathbf{4 8} \mathbf{~ h}$ & $\mathbf{2 4} \mathbf{~ h}$ & $\mathbf{4 8} \mathbf{~ h}$ \\
\hline CONTROL & 11.5 & 11.5 & 10.6 & 10.6 \\
\hline HYDRATION & 12.2 & 12.7 & 11.3 & 11.9 \\
\hline KNO $_{\mathbf{3}}(\mathbf{5 0 m M})$ & 12.9 & 13.5 & 12.4 & 13.0 \\
\hline KNO $_{\mathbf{3}}(\mathbf{1 5 0} \mathbf{m})$ & 13.7 & 14.4 & 13.1 & 13.7 \\
\hline GA $_{\mathbf{3}}(\mathbf{1 0 p p m})$ & 14.6 & 15.0 & 13.8 & 14.5 \\
\hline GA $_{\mathbf{3}}(\mathbf{2 0} \mathbf{p p m})$ & 15.2 & 15.6 & 14.7 & 15.1 \\
\hline CD at 5\% & \multicolumn{3}{|c|}{$\mathrm{A}=0.8205, \mathrm{~B}=\mathrm{NS}, \mathrm{C}=\mathrm{NS}, \mathrm{ABC}=\mathrm{NS}$} \\
\hline
\end{tabular}

Table 5:- Effect of seed priming for 24 and $48 \mathrm{hrs}$ on root length (cms) of seedlings of two tomato (Lycopersicon esculentum L.) cultivars Varkha Bahar-1 and Varkha Bahar-2.

\begin{tabular}{|l|c|c|c|c|}
\hline \multirow{2}{*}{ TREATMENTS } & \multicolumn{2}{|c|}{ VARKHA BAHAR-1 } & \multicolumn{2}{c|}{ VARKHA BAHAR-2 } \\
\cline { 2 - 5 } & $24 \mathrm{~h}$ & $48 \mathrm{~h}$ & $24 \mathrm{~h}$ & $48 \mathrm{~h}$ \\
\hline
\end{tabular}




\begin{tabular}{|l|c|c|c|c|}
\hline CONTROL & 4.7 & 4.7 & 4.3 & 4.3 \\
\hline HYDRATION & 5.3 & 5.6 & 4.8 & 5.2 \\
\hline KNO $_{\mathbf{3}}(\mathbf{5 0 m M})$ & 5.7 & 6.2 & 5.3 & 5.8 \\
\hline KNO $_{\mathbf{3}}(\mathbf{1 5 0 m M})$ & 6.2 & 6.7 & 5.9 & 6.3 \\
\hline $\mathbf{G A}_{\mathbf{3}}(\mathbf{1 0 p p m})$ & 6.7 & 7.2 & 6.4 & 6.9 \\
\hline GA $_{\mathbf{3}}(\mathbf{2 0 p p m )}$ & 7.3 & 7.7 & 7.0 & 7.4 \\
\hline CD at 5\% & \multicolumn{2}{|c|}{$\mathrm{A}=0.8205, \mathrm{~B}=\mathrm{NS}, \mathrm{C}=\mathrm{NS}, \mathrm{ABC}=\mathrm{NS}$} \\
\hline
\end{tabular}

Table 6:- Effect of seed priming for 24 and $48 \mathrm{hrs}$ on vigour index of two tomato (Lycopersicon esculentum L.) cultivars Varkha Bahar-1 and Varkha Bahar-2.

\begin{tabular}{|l|c|c|c|c|}
\hline \multirow{2}{*}{ TREATMENTS } & \multicolumn{2}{|c|}{ VARKHA BAHAR-1 } & \multicolumn{2}{c|}{ VARKHA BAHAR-2 } \\
\cline { 2 - 5 } CONTROL & $\mathbf{2 4} \mathbf{~ h}$ & $\mathbf{4 8} \mathbf{~ h}$ & $\mathbf{2 4} \mathbf{~ h}$ & $\mathbf{4 8} \mathbf{~ h}$ \\
\hline HYDRATION & 479.75 & 479.75 & 436.5 & 436.5 \\
\hline KNO $_{\mathbf{3}}(\mathbf{5 0 m M})$ & 640.68 & 709.20 & 539.72 & 606.04 \\
\hline KNO $_{\mathbf{3}}(\mathbf{1 5 0 m M})$ & 763.56 & 872.48 & 673.92 & 750.20 \\
\hline GA $_{\mathbf{3}}(\mathbf{1 0 p p m})$ & 859.95 & 975.72 & 778.68 & 869.82 \\
\hline GA $_{\mathbf{3}}(\mathbf{2 0 p p m})$ & 983.84 & 1117.20 & 872.52 & 1009.44 \\
\hline CD at 5\% & 1081.74 & 1283.52 & 1005.29 & 1143.90 \\
\hline
\end{tabular}

$\mathrm{A}=$ Variety

$\mathrm{B}=$ Treatment

$\mathrm{C}=$ Time

\section{References:-}

1. Ahmadvand G, Soleimani F, Saadatian B and Pouya M (2012a) Effect of seed priming with potassium nitrate on germination and emergence traits of two soybean cultivars under salinity stress conditions. AmericanEurasian J Agric Environ Sci 12: 769-74.

2. Ahmadvand G, Soleimani F, Saadatian B and Pouya M (2012b) Effect of seed priming on seed germination and seedling emergence of cotton under salinity stress. World Appl Sci J 20: 1453-1458

3. Ashraf M and Foolad R M (2005) Pre-sowing seed treatment - a shotgun approach to improve germination, plant growth and crop yield under saline and non-saline conditions. Advances in Agronomy 88: 223-71.

4. Choudhury S, Islam N, Sarkar M D and Ali M A (2013) Growth and Yield of Summer Tomato as Influenced by Plant Growth Regulators. International Journal of Sustainable Agriculture 5(1): 25-28.

5. Patel Y K and Rai P K (2018) Effect of Seed Priming on Seed Quality of Tomato (Solanum lycoperscium L.). The Pharma Innovation Journal 7(2): 264-26.

6. Paparella S, Araújo S S, Rossi G, Wijayasinghe M, Carbonera D and Balestrazzi A (2015) Seed priming: state of the art and new perspectives. Plant Cell Reports 34: 1281-93.

7. Hussain S, Khan F, Hussain H A and Nie L (2016) Physiological and biochemical mechanisms of seed priminginduced chilling tolerance in rice cultivars. Frontiers in Plant Science 7:116.

8. Zhang M, Wang Z, Yuan L, Yin C, Cheng J, Wang L (2012) Osmopriming improves tomato seed vigour under aging and salinity stress. African J Biotech 11(23): 6305-11.

9. Abdul-Baki A S and Anderson J D (1973) Vigour determination in soybean by multiple criteria. Crop Sci 13: 630-33.

10. ISTA (2008) International Rules For Seed Testing. ISTA, Bassersdr of CH. Switzerland.

11. Kathiresan K, Kalyani V, Gnanarethium J L (1984) Effect of seed treatments on field emergence, early growth and some physiological processes of sunflower (Helianthus annus L.). Field Crops Research 9: 255-59.

12. Bakht J, Shafi M, Jamal Y, Sher H (2011) Response of maize (Zea mays L.) to seed priming with $\mathrm{NaCl}$ and salinity stress. Spanish J. of Agricultural. Research 9(1): 252-61.

13. Ruan S, Xue Q, Tylkowska K (2002) The influence of priming on germination of rice (Oryza sativa L.) seeds and seedling emergence and performance in flooded soil. Seed Science \& Technology 30: 61-67.

14. Patade V Y, Maya K and Zakwan A (2011) Seed priming mediated germination improvement and tolerance to subsequent exposure to cold and salt stress in capsicum. Research Journal of Seed Science 4:125-36.

15. Ghassemi G, Alito A A, Valizadahe M and Moghaddam M (2008) Effect of hydro and osmo priming on germination and field emergence of lentil. Hort Agrobot (Online) 36 (1): 29-33. 
16. Harris D (2002) On-farm seed priming to increase yield of crops and reduce risk of crop failure in marginal areas of developing countries. Second international agronomy congress on balancing food and environmental security a continuing challenge. New Delhi 2002. (Indian Society of Agronomy). Indian council of agricultural research, pp. 1509-1511.

17. Bradford K J, Steiner J Jand Trawatha S E (1990) Seed priming influence on germination and emergence of pepper seeds. Crop Science 30: 718-21.

18. Zhang M, Wang Z, Yuan L, Yin C, Cheng J, Wang L et al (2012) Osmopriming improves tomato seed vigour under aging and salinity stress. African J Biotech 11(23): 6305-11.

19. Govinden S J and Levantard M (2008) Comparative studies of seed priming and pelleting on percentage and meantime to germination of seeds of tomato (Lycopersicon esculentum Mill.). African J Agric Res 3(10): 72531.

20. Demir I and Oztokat C (2003) Effect of salt priming on germination and seedling growth at low temperatures in water melon seeds during development. Seed Science Technology 31: 765-70.

21. Farooq M, Basra M A, Tauseef M, Rehman H and Munir H (2007) Priming with ethanol, ascorbate and salicylicate enhances the germination and early seedling growth of pea (Pisum Sativum L.). Pakistan Journal of Agriculture Science 44 (1): 2.

22. Nascimento W M (2003) Muskmelon seed germination and seedling development in response to seed priming. Scientia Agricola 60 (1): 71-75. 